\title{
Environmental Degradation and Poverty in Amansie Traditional Area: Investigating the Contributing Factors and the Role of Religion
}

\author{
Charles Owusu Ampofo ${ }^{1}$ \\ ${ }^{1}$ Department of Religious Studies, Kwame Nkrumah University of Science and Technology, Ghana.
}

\begin{abstract}
Environmental degradation and poverty are challenges faced in most parts of the world, and the global quest by some researchers to know the role religious bodieson should play in relation to these issues of concern continues unabated. The ripple effect of these challenges manifests in many areas such as socially, economically, morally, and spiritually. However, the prevailing factors within localities vary, hence requiring wholistic investigations peculiar to a community. Notably, these challenges cannot only be addressed by Government hence the call on Rreligious Bodiesn as an institution to assist in curbing this menace. This paper investigates the factors contributing to environmental degradation and poverty in Amansie Traditional Area and the role religion should play in addressing these challenges. Questionnaires and interviews were administered to assess these factors from townsfolks, religious leaders, institution heads, and other stakeholders. The results revealed significant factors contributing to these challenges and the roles both African Tradition and Christianity should play in addressing these challenges. The study recommends a strong collaborative effort from all stakeholders, especially religious institutions, in educating and sensitizing the people of Amansie on the issues of environmental sustainability and poverty alleviation.
\end{abstract}

Keywords: Environmental degradation, poverty, religion, African Traditional Religion, Christianity.

(C) 2020 The Author(s). Published and Maintained by Noyam Publishers.

This is an open access article under the CCBY license (http://creativecommons.org/licenses/by/4.0/).

\section{INTRODUCTION}

The World Commission on Environment and Development (WCED) reports that, "Poverty is a major cause and effect of global environmental problems", and that many parts of the world are caught in a vicious downwards spiral. ${ }^{2}$ It means that poor people are forced to overuse environmental resources to survive. Poverty and environmental degradation seem to be inextricably linked and are mutually self-enforcing. The consequence is the degradation of the environment, and such degradation, in turn, perpetuates more poverty. There seems to be extensive illegal mining and its concomitant environmental degradation in Amansie Traditional Area which has commonly had led to a vicious cycle of poverty among the populace. With both Christianity and Traditional Religious adherents constituting 77.8 and 86.4 percent of the Amansie population respectively, it is thought that religion should be involved a major factor in building up a sustainable society. ${ }^{3}$

This disposition is motivated by the fact that religion seeks an equilibrium among nature, divine, and humankind, hence creating a positive impression on nature sustainability and enhancing human well-being. Amansie, though blessed with mineral resources, forests, agricultural lands, and water bodies is yet considered one of the poorest districts in the Ashanti Region of Ghana. This is partly possible because of the ongoing environmental degrading activities which impact is largely felt in the reported loss of forest zones, agricultural lands, and water stress leading to uneven distribution of economic resources. Even though there were government social intervention programmes, these have not been enough hence the question of, what role religion should play in curbing these menaces, since the causes of these challenges are

\footnotetext{
World Commission on Environment and Development. Our common future: The Report of the World Commission on Environment and Development. (Oxford: Oxford University Press, 1987), 3.

Ghana Statistical Service. 2010 Population and Housing Census. District Analytical Report: Amansie West District, May 2013:63.
} 
beyond socioeconomic factors. Based on this background, this study seeks to investigate the contributing factors to environmental degradation and poverty in the Amansie Traditional Area and the role religion can play in addressing these challenges.

\section{ENVIRONMENTAL DEGRADATION}

The destruction or depletion of potentially renewable resources faster than it can be naturally renewed describes the concept of environmental degradation. ${ }^{4}$ This, therefore, compromises the state of the serene nature of the natural order of things. As a critical global concern, many International organizations and conferences have informed and placed premium on the current state of the global climate change, biological diversity, and deforestation. ${ }^{5}$ This raises queries against the status quo of the erstwhile environmental practices and principles. Many scholars such as Borgmann, Neubeck et al, and Coates have also given credence to some factors which cause environmental degradation. ${ }^{6}$ These factors vary from a setting to another hence the need for a thorough investigation and the conditions peculiar to a particular setting.

\section{The Interplay of Religion and Environmental Degradation}

Religion from time immemorial to date appears to form the rich soil of memory and practice, belief, and relationship where life on earth is rooted. Religious ideas, therefore, do not just contend with other ideas as equals, since they frame the mind-set within which all sorts of ideas relate in the Africans' cosmology. ${ }^{7}$ Dewitt believes that using religious ideas to engage with environmental degradation is an important phenomenon. ${ }^{8}$ This he argues can transform the perspectives of humans about nature. It is important therefore that, people are equipped with religious knowledge and traditions to influence their behaviour towards themselves and the world around them (e.g. environmental soundness and a vicious circle of poverty). For the African Religious communities, the remote causes are embedded in the manipulation of their religio-cultural worldview. Hence, to the African religious conscience, environmental challenges should first be referred to as a spiritual crisis, then second, as an outgrow of modernity, whose fundamental values are enshrined in Western civilization.

\section{The General Concept of Poverty}

Poverty is a human condition and is well understood by the causal agents which can be anything from economic, political, socio-cultural, and even religious. Poverty has been linked in time past as the lack of financial resources and assets. However, many recent studies by researchers such as Goulden, ${ }^{9}$ and Forsyth et al suggest that income-based definitions of poverty have been too narrow as it had been contextually inappropriate for the developing countries. ${ }^{10}$ For Townsend, poverty is apparent when there is a failure to keep with the standards prevalent in a given society ${ }^{11}$. This presupposes that poverty encompasses things other than strictly material needs. Such a standard of measurement is thoughtful enough and will serve as a relevant guide for answering questions such as, how does the analysis of religious thoughts and traditions impact the use of the environment and the poverty situation of the people?

\section{The Interplay of Religion and The Issues of Poverty}

The African communities intertwine with the belief systems and practices which in aggregate constitute the culture of the people; consequently, the issue of poverty amongst Africans is as much a religious problem as social. Like other religious civilizations, the African religious consciousness depicts the meaning and implications of poverty through myths, proverbs, and uses prohibitions that support, protect, or relieve the poor and the destitute from their plight. ${ }^{12}$ Similarly, the Church has also continued to participate in the fight against poverty as a way of accomplishing its ministry which is about Jesus Christ's mission to serve and minister to all, both rich and poor of the World (Mk. 10:21, 6:36; Lk.

\footnotetext{
4 Chris Park, Oxford Dictionary of Environment and Conservation. (UK: Oxford University Press, 2008), 150.

5 United Nations (1987)."Report of the World Commission on Environment and Development: Our Common Future, from one Earth to one World." General Assembly Resolution 42/187. Accessed October 29, 2017. http://www.un.org/documents.

6 John Coates, "Exploring the Roots of the Environmental Crisis: Opportunity for Social Transformation." Critical Social Work, Vol 4, No.1, 2003:147-157; Paul Ehrlich and A. Ehrlich, The Population Bomb Revisited. The Electronic Journal of Sustainable Development (2009) 1(3), 64-71; Albert Borgmann, Technology and the Character of Contemporary Life: A Philosophical Inquiry. (Chicago: University of Chicago Press, 1984).

Lawrence E. Sullivan. "Preface," in Christianity and Ecology. Dieter Hessel and Rosemary Ruether (ed.). (USA: Harvard University Press, 2000), xi - xiv.

8 Calvin B. Dewitt, "Behemoth and Batrachians in the Eyes of God: Responsibility to other Kinds in Biblical Perspective," in Dieter Hessel and R. Ruether (eds.) Christianity and Ecology (Cambridge: Harvard University Press, 2000), 297.

9 Chris Goulden, Joseph Rowntree Foundation. Accessed August 16, 2017. www.jrf.org.uk/anti-poverty/publications 2014:5.

10 Tim Forsyth, M. Leach, and I. Scoones. Poverty and environment: priorities for research and policy (Prepared for the United Nations Development Programme and European Commission). (UK: Institute of Development Studies, 1998), 17-19.

11 Peter Townsend, The Concept of Poverty. (London: Heinemann, 1979), 31.

12 Obaji Agbiji and Ignatius Swart, Religion and Social Transformation in Africa: A critical and appreciative perspective. Scriptura 114 (2015):1-20.
} 
12:33, 16:19-31 Matt 25: 42-43). ${ }^{13}$ Hence religion remains one of the major stakeholders of poverty alleviation agency, especially in the rural areas.

\section{METHODOLOGY}

The focus of the methodology which was to examine the religious response to environmental degradation and poverty can be located within the framework of empirical studies, in Religious studies. In this study, the researcher utilized both primary and secondary sources of data. The primary sources explored information via interviews, semi-structured questionnaires, field data collection, and field observation to give a detailed and clear understanding of the objective of the study. The research was conducted in Amansie West District in the Ashanti Region of Ghana with a population of $134,331 .{ }^{14}$ and respondents ranging from religious leaders, the rural folks, civic leaders, farmers, and miners serving as key informants. The biophysical characteristics of the study area were also analyzed to assess the degree of destruction of the natural environment. Due to the nature of the study, data on household income and religion was obtained. The qualitative method used was interactional and interpretive using a descriptive survey design which provides an accurate account of the characteristics, for example, behaviour, opinions, abilities, beliefs, and knowledge of a particular individual, situation, or group. ${ }^{15}$ Interviews were conducted in the local language of respondents as this allowed a high responsive rate, and was able to draw-out in-depth information. Questionnaires were answered with the aid of the researcher for clarity. Frequencies and percentages were employed to analyze the data obtained. Recorded information from interviews were transcribed and were coded under the various themes for further analysis.

\section{RESULTS AND DISCUSSION}

\section{Factors in Amansie contributing to Environment degradation}

Amansie communities are blessed with natural resources hence, it is expected that these resources would be managed and exploited in an environmentally friendly and culturally appropriate manner to the benefit of everyone. However, from the results obtained from the survey conducted, it was revealed that environmental degradation is on the rise with 97 percent of respondents confirming the challenge. The various stakeholders within the communities indicated through the study their consciousness of the challenge of environmental degradation. This admission reveals a continuous and impending tragedy of human survival. Illegal mining and unauthorized lumbering are major elements of degradation in the area. Members of the communities continue to lament on land degradation and the degree of air and water pollution for the past decades. This challenge is as a result of anthropogenic interactions with the natural environment. The negative effect of this challenge impacts on the livelihood and serves as a possible threat to the present and future survival of the communities.

The factors contributing to environmental destruction ranged from socioeconomic to moral and ethical disciplines. All the factors presented here had a score above 78 percent, hence the need for much attention to these destructions. Illegal mining operations are the highest and the severest contributor to environmental degradation in Amansie Traditional Area with 97 percent of stakeholders choosing the factor. As artisanal and small-scale mining increases in Ghana, farmers and labourers from the agriculture sector have now moved into the supposed lucrative mining sector. Lack of job opportunities and the poverty situation in Amansie emerged as a key driving force for the movement into the illegal mining activities. The presence of some foreign miners especially the Chinese have been a great influence leading to the inhumane attitude to the natural environment with the involvement of large earthmoving types of machinery for mineral exploration.

Improper timber logging in forest reserves emerged as the second cause of environmental degradation in the area. Illegal chainsaw alone accounts for about 84 percent of local lumber supply; and it is believed to employ about 130,000 people in Ghana. ${ }^{16}$ This has led to the destruction of Apanprama, Jimira, Oda, and Gyeni River Forest Reserves which hosted various species of flora and fauna. ${ }^{17}$ Farmlands within the area have been encroached upon, with most efforts to curtail this challenge proving futile. In Amansie, poverty emerged as the third cause of environmental degradation, with 90 percent of respondents confirming this. The lack of employment forces the majority of the youth into environmental degradation in the quest of seeking good livelihoods. The income of the people within the traditional area was found to be extremely lower than the national average and with the nature of the work in the community, not much is earned or saved. Lucrative forms of jobs are given to foreigners who have higher qualifications than the locals rendering some locals

\footnotetext{
13 Joshua Ayiemba et al, “The mandate of the Christian church in poverty alleviation," International Research Journal of Arts and social Science Vol. 4(2)43-54, February, 2015

14 Ghana Statistical Service, Ghana Districts, A resource base for all local assemblies in Ghana. Accessed November 20, 2017. http://www.ghanadistricts.com/ Home/amansiewest

15 Nancy Burns and Susan Grove, The practice of nursing research: conduct, critique, and utilization. (Philadelphia: W. B. Saunders Company, 1993 ), 29.

16 Ghana's forests now cover 1.6million hectares. Accessed February 16, 2020. https://www.ghanaweb.com/GhanaHome/business

7 Ministry of Food and Agriculture, Amansie West district. Accessed February 18, 2020. https://mofa.gov.gh/district-directorates/ashanti-region
} 
jobless. From the study, it was revealed that population growth among the locals has increased hence placing stress on the limited but priceless resources in the communities. Again, the poor farming and fishing practices by some locals have led to the destruction of land and water bodies. This has further led to the destruction of food crops, flora, and fauna of different species. This factor, therefore, emerged as one of the main contributors to environmental degradation. One of the moral factors that emerged as a contributor to environmental degradation was the lack of fear for religious prohibitions. In a typical traditional setting, guided by prohibitions in forms of myths, taboos, and penalties, most people, especially the youth have little regard for these laws hence had ended up destroying the natural environment. It was revealed further that, some bad attitudes of these perpetrators were somehow influenced by the systemic failure in the traditional and religious institutions of the area. That is, the weakness or leniency of the deities, as well as leniency of traditional leaders who rarely chastise perpetrators when summoned to the traditional courts and royal palaces Again, it was observed that the young people had either been recalcitrant or ignorant of cultural and religious issues, for which reason they should be educated.

\section{Factors in Amansie contributing to Poverty}

This study found that Harrison's view of issues of poverty is very relevant for this setting, especially, when it included lack of fertile land, denial of land, inequality, injustice, blatant ruthlessness, and violent exploitation. ${ }^{18}$ The causal factors of poverty ascertained from the study were revealed as follows: the lack of unemployment issues, misuse of natural resources, the individual deficiencies, the geographical disparities, the increasing population growth.

The impact of unemployment was revealed as the largest contributor to poverty in Amansie with 89 percent of the respondents confirming. This reality in the traditional area had been due to the shortfall of decent job opportunities. The challenge of unemployment though a national problem is largely felt in rural settings. The Amansie communities are rather flooded with periodic job opportunities that do not guarantee the long-term economic survival of the people. Farmers within these localities become financially stranded due to the seasonality of their work.

It was revealed from the study that, the impact of mining activities is also a large contributor to the poverty situation in Amansie. Some local businesses have been affected owing to the destructive nature of illegal mining operations. Fishermen whose livelihood depended on river bodies are economically challenged due to the high pollution of water bodies. This is through the introduction of some chemicals such as cyanide and mercury into the water bodies which ended up destroying the fishes in them. Agricultural lands and farmers have not been spared from the negative impact of the illegal mining activities in the area as some farmlands have been encroached on by illegal miners and others influenced to sell their lands sometimes for lump-sum financial rewards.

Again, it was revealed that the impact of population growth on poverty has been highly felt. There is the upsurge of migrants into the traditional area in search of farming and mining opportunities, hence increasing the population within the area. There is has been a breed of competition for resources causing the less fortunate to continue struggling. Though not financially sound, most rural folks in Amansie continue to give birth in large numbers. This had usually been fuelled by teenage pregnancies, lack of family planning, and the use of contraceptives, and also some polygamous marriages. All these factors in turn lead to the continuous stretch of economic resources.

The high sense of individuality which kills the communal spirit is also a contributor to poverty in Amansie Traditional Area. The typical African society which was built on togetherness and support for one another was revealed from the study to be gradually going extinct. The needy local farmers do not receive support from colleagues; and many family members today do not render support to their families without the expectation of some favours. This means that individuals in need would remain poor if they are unable to support themselves. This has consequently been found to be one of the motivations for the involvement of people in environmental degradation.

\section{The role religion should play in addressing issues of environmental degradation}

Responses from most people during the survey revealed a high level of expectation towards religious leaders and religion at large. These expectations as well as observations and analysis by the researcher informs the role religion should play in addressing these challenges. These roles are targeted at providing religious solutions to the challenge of environmental degradation and issues of poverty and the salient ones are presented below:

To address the challenge of environmental degradation, it was discovered that an advanced collaborative effort by all stakeholders should be encouraged. From the survey, efforts had been made by both the African Traditional Religion and Christianity but in most cases from varying standpoints. However, a more collaborative effort would increase the impact made by religion towards these challenges. This effort would bring together different stakeholders from government agencies, traditional and religious groups, mining, lumbering, and farming associations. With the impact of environmental degradation being wide, affecting economic, health, education, safety, and many more, stakeholders from various expertise could be assembled to design and develop a comprehensive scheme to confront these menaces.

\footnotetext{
18 Paul Harrison, Inside the Third World. The anatomy of poverty. (England: Penguin, 1981), 66.
} 
This would not only encourage team effort but also promote accountability. The religious leaders can easily create such platforms through events and durbars, as compared to other institutions. This confirms Gardner's notion that religion has the ear of multitudes of adherents as well as possessing a strong institutional asset for development ${ }^{19}$

Again, another role religion should play from the study is the creation of more avenues for education and advocacy in addressing issues relating to environmental sustainability. There is a need to educate the younger generation and most locals on ensuring that the natural environment is well preserved. Such exercise should be enforced by the custodians of tradition and religion. The church and traditional leaders have the responsibility of teaching the members of the communities to be morally upright and this calls for more avenues for advocacy and education. Church meetings, community information centers, durbars, and regular gatherings should be for frequent avenues for education and sensitization programmes. With more of such rigorous interventions, a possible change in the mindsets and attitudes of people can be achieved.

The reinforcement of laws related to the protection of the natural environment can be roles religious leaders should be encouraged to play. Traditionally, prohibitions such as myths that serve as deterrents should be enforced by the traditional leaders. During the survey in Amansie, some traditional leaders shared stories of people who broke water taboos by entering its confines in sacred days and ended up bumping into scary objects. A story was told of one such an offender who encountered a river goddess bathing her children in the river and dying after announcing the encounter. Some leaders in recent times have been seen to be lenient towards their role as custodians of the lands and culture. In cases where offenses are damaging, collaborating with security agencies to arrest and prosecute culprits should be encouraged. Churches should be encouraged to remind their members of actions that are damaging to society and the need to desist from them. This can be well achieved through conscious biblical teachings on the subject matter.

Christian groups and churches in their bid to support the issue of environmental sustainability should encourage their membership on embarking on communal exercises since they are taught by the Bible to be examples in the communities, they find themselves (Matt 5: 13-16). Communal social campaigns such as periodic clean-ups, educational seminars, development of welfare schemes, and support aids could bring this function of responsibility into being. In some cases, these religious institutions can provide adequate infrastructure and equipment to the communities as a matter of supporting the vision of environmental sustainability.

\section{The role religion should play in addressing issues of poverty}

The religious leadership of Amansie owe the responsibility of ensuring the wellbeing of the members of the community and to achieve this, they have to marry their mandated responsibilities with the expectations of the people. These expectations call for the creation of extra room for more work to be done by the religious leaders in the direction of alleviating poverty and creating wealth from the available stock of natural resources in the community. Although some efforts had been made by some religious leaders in supporting the community, careful analysis from the study revealed that it had not been enough. Consequently, religious institutions should make extra efforts in addressing the issues of poverty.

Increasing the collaborative efforts by both religion towards community development should be a prior concern to the leadership. In Amansie there is a high youthful population that had further increased the dependency ratio. ${ }^{20}$ This implies that leaders should be focusing more on the development of human capital through skill training and education. Ensuring human resource development could mean building the capacity of members, and one way to achieve such a goal is to be equipping members with the requisite financial and economic knowledge for addressing issues of poverty. Market women, farmers, and small-scale businesses in Amansie have in the past struggled in acquiring loan facilities due to the collateral requirement. Therefore, religious collaboration could create a haven for the financial and economic support base for the entrepreneurs. A lot more material assistance can as well be made available to the impoverished, especially the widows and orphans in the community.

A combined effort of all stakeholders to create a synergistic effort in job creation should be promoted by the religious leadership of Amansie. In this case, various parties can bring onboard the resources that are available to them, be it human resources, natural resources (land), or financial support. Some of these job opportunities would require strong financial capital which can be realized if religious leaders should initiate special fundraising projects and annual communal levy. Additionally, transforming the existing jobs to be more lucrative to target especially the youth should be highly considered. From the survey, it was again revealed that the youth had lost interest in agricultural practices such as farming which has forever been one of the strongest backbones of the Ghanaian economy. To be able to arrest this challenge, partnership with some government institutions and private partnerships should be fostered, and the religious

\footnotetext{
9 Gary Gardner, Invoking the Spirit: Religion and Spirituality in the quest for sustainable World. (USA: Worldwatch Institute, 2002), 35

202010 Population and Housing Census. Ghana Statistical Service. District Analytical Report: Amansei West District, October 2014:15.
} 
leaders could by themselves serve as platforms to encourage such interventions.

The provision of financial support for the needy and vulnerable in society should be an inspired role of the religious leaders. Though some churches within the community provide some sort of financial assistance to their members, these initiatives are usually not extended to the communities at large. In some sense, this challenge can be attributed to financial constraints and the numerous commitments of these religious institutions. However, it should be noted that rendering support to people should not be restricted to monetary forms. Creating alternative livelihood programs can ensure a regular flow of income and the average living standard of the people.

\section{RECOMMENDATIONS}

Consequently, the role of religion is expected to ameliorate the effect of environmental degradation and issues of poverty through the following actions: Religious people and institutions should be strongly involved in educating and sensitizing town folks on issues about Environment sustainability and Poverty Alleviation Programmes. Also, there should be religiocultural resurgence which when promoted will ensure that the dignity and sanctity of nature are adhered to, and that, social harnessing values and practices are revitalized. Finally, a strong collaborative effort by various stakeholders would go a long way to solicit for new and improved ideas to address the impending challenges, while designing comprehensive and robust schemes to improve the well-being of the people and ensuring environmental sustainability.

\section{CONCLUSION}

The Amansie community, though blessed with natural resources, has many of the local folks who continue to remain poor, even though it is expected that these resources would be sustainably administered and exploited in a manner that would be environmentally friendly, culturally appropriate, and economically beneficial to the entire community. This study, therefore, investigated the peculiar causal agents of environmental degradation and poverty, and how religious bodies had contributed to influence the state of affairs in the traditional area. The study revealed that, the nature of the environment had rather been impacted by anthropogenic factors stemming from a surge in artisanal mining activities, illegal lumbering activities, high levels of poverty, lack of adherence to religious prohibitions to misapplication of farming methods and practices. Regarding the causal factors of poverty as ascertained in the study, the following factors were observed: the lack of fertile land, lack of decent employment opportunities, misuse of natural resources, the impact of population growth, and the high sense of individuality within the community. This paper further revealed that religion possesses some sources of power which could be useful for ensuring environmental sustainability and improving the economic livelihood of the people.

\section{ABOUT AUTHOR}

Charles Owusu Ampofo is an ordained minister of the Ghana Baptist Convention and is currently serving at the Victory Baptist Church, Kumasi-Ghana. Presently, he is the sitting president of the Baptist Ministers' Conference and has in the past lectured in the Seminary. He is currently a PhD candidate in the Department of Religious Studies (KNUST), and holds a PGDE (UCC), MA. (ACT), and MPhil. (KNUST). He has research interests in exploring relationships between religion and environment, and religion and poverty.

\section{BIBLIOGRAPHY}

Agbiji Obaji and Ignatius. Religion and Social Transformation in Africa: A critical and appreciative perspective. Scriptura 114 (2015): 1-20. https://doi.org/10.7833/114-0-1115

Ayiemba, J. et al. "The mandate of the Christian church in poverty alleviation," International Research Journal of Arts and social Science Vol. 4(2), 2015:43-54. http:/dx.doi.org/10.14303/irjass.2014.054

Borgmann, Albert. Technology and the Character of Contemporary Life: A Philosophical Inquiry. Chicago: University of Chicago Press, 1984.

Burns, Nancy and Grove, Susan. The practice of nursing research: conduct, critique, and utilization. Philadelphia: W. B. Saunders Company, 1993.

Coates, John. "Exploring the Roots of the Environmental Crisis: Opportunity for Social Transformation." Critical Social Work, Vol 4, No.1, 2003:147-157.

Dewitt, Calvin B. "Behemoth and Batrachians in the Eyes of God: Responsibility to other Kinds in Biblical Perspective," in Dieter Hessel and R. Ruether (eds.) Christianity and Ecology. Cambridge: Harvard University Press, 2000.

Ehrlich, Paul and A. Ehrlich. The Population Bomb Revisited. The Electronic Journal of Sustainable Development (2009) $1(3), 64-71$. 
Forsyth, Tim, M. Leach, and I. Scoones. Poverty and environment: priorities for research and policy (Prepared for the United Nations Development Programme and European Commission). UK: Institute of Development Studies, 1998.

Gardner, Gary. Invoking the Spirit: Religion and Spirituality in the quest for sustainable World. USA: Worldwatch Institute, 2002.

Harrison, Paul. Inside the Third World. The anatomy of poverty. England: Penguin, 1981.

Ghana Statistical Service. 2010 Population and Housing Census. District Analytical Report: Amansie West District, May 2013.

Ghana’s forests now cover 1.6million hectares. Accessed February 16, 2020. https://www.ghanaweb.com/GhanaHome/ business

Ghana Statistical Service. Ghana Districts, A resource base for all local assemblies in Ghana. Accessed November 20, 2017. http://www.ghanadistricts.com/Home/amansiewest

Goulden, C. and J. Rowntree Foundation. Accessed August 16, 2017. https://www.jrf.org.uk/anti-poverty/publications

Ministry of Food and Agriculture, Amansie West district. Accessed February 18, 2020. https://mofa.gov.gh/district-directorates/ashanti-region

Park, Chris. Oxford Dictionary of Environment and Conservation, UK: Oxford University Press, 2008.

Sullivan, Lawrence E. "Preface," in Christianity and Ecology. Dieter Hessel and Rosemary Ruether (ed.). USA: Harvard University Press, 2000.

Townsend, Peter. The Concept of Poverty. London: Heinemann, 1979.

United Nations (1987)."Report of the World Commission on Environment and Development: Our Common Future, from one Earth to one World." General Assembly Resolution 42/187. Accessed October 29, 2017. http://www.un.org/documents.

World Commission on Environment and Development. Our common future: The Report of the World Commission on Environment and Development. Oxford: Oxford University Press, 1987. 